\title{
Pseudomonas viridiflava in imported carrot seeds
}

\author{
I. M. G. Almeida • K. W. Maciel • J. Rodrigues Neto • \\ L. O. S. Beriam
}

Received: 11 January 2012 / Accepted: 26 November 2012 /Published online: 9 December 2012

(C) Australasian Plant Pathology Society Inc. 2012

\begin{abstract}
In 2005, a sample of carrot seeds var. Kikuyo imported from Japan was submitted to the Instituto Biológico for bacteriological phytosanitary certification. Circular, convex and creamy colored colonies were obtained. These isolates produced a green fluorescent pigment on King's B medium and incited a hypersensitivity reaction in tobacco leaves. They were oxidase and arginine dihydrolase negative, did not produce levan but caused soft rot in potato slices and were identified as Pseudomonas viridiflava. Artificial inoculations by infiltration of bacterial suspensions at the crown area or by placing a drop of bacterial suspension on this area and pricking with a sterile needle, produced light to dark brown areas around the injured points 5 days after inoculation. The bacterium was then re-isolated. Although this bacterium could be an opportunistic pathogen and was isolated from asymptomatic samples, eventual losses in the field and postharvest storage is possible.
\end{abstract}

\section{Keywords Daucus carota - Pseudomonas viridiflava .} Bacterial-seed detection

In 2005, a sample of carrot seeds var. Kikuyo imported from Japan was submitted to the Instituto Biológico for phytosanitary certification. The test used to detect pathogenic bacteria consisted of extraction and isolation on culture medium followed by identification.

The carrot seed samples were soaked in sterile saline solution ( $6 \mathrm{~g}$ of seeds: $10 \mathrm{~mL}$ of saline) overnight at $4{ }^{\circ} \mathrm{C}$ prior to extraction. Thereafter, aliquots of $100 \mu \mathrm{L}$ of the infusion of soaked seeds were spread onto the surface of plates

I. M. G. Almeida $(\bowtie) \cdot$ K. W. Maciel $•$ J. R. Neto $\cdot$ L. O. S. Beriam Instituto Biológico, Caixa Postal 70, CEP 13012-970, Campinas, SP, Brazil

e-mail: gatti@biologico.sp.gov.br containing culture medium (nutrient agar plus $40 \mathrm{mg} / \mathrm{L}$ of cycloheximide), and the plates incubated for 3 to 5 days at $27^{\circ} \mathrm{C}$. Circular, convex and creamy colored colonies were obtained. Single colony bacterial isolates produced a green fluorescent pigment on King's B medium (King et al. 1954), and incited a hypersensitivity reaction in tobacco leaves. They were oxidase and arginine dihydrolase negative, did not produce levan but caused soft rot in potato slices and according to Lelliott et al. (1966) belonged to group II of Pseudomonads and were identified as Pseudomonas viridiflava.

Twenty healthy carrot plants containing tuberous roots were inoculated either by infiltration of bacterial suspensions (ca. $10^{8} \mathrm{CFU} / \mathrm{mL}$ ) to the crown area of the root or by placing a drop of bacterial suspension on this area and then pricking the root with a sterile needle to introduce the bacterial cells into the tissues. Control plants were inoculated by both methods with sterile distilled water. After the inoculation, plants were placed in a humidity chamber for $72 \mathrm{~h}$, and then transferred to a greenhouse.

In addition, surface-sterilized carrot root slices were placed in sterile Petri dishes and inoculated by swabbing cultures of the bacterium over their surfaces under aseptic conditions (five plates total). The plates were incubated at $28{ }^{\circ} \mathrm{C}$ for $24 \mathrm{~h}$. Carrot slices which were inoculated with sterile distilled water were maintained as controls.

Inoculated plants were examined daily for 2 weeks to observe disease development. Light to dark brown areas were observed around the injured points 5 days after inoculation. Longitudinal sections of the roots showed complete tissue degradation progressing downward from the crown to the root tip (Fig. 1). Re-isolation from the infected tissue yielded $P$. viridiflava isolates identical to those isolated from carrot seed, which was confirmed by biochemical, cultural and biological tests.

The inoculated carrot slices showed severe rotting 72 $96 \mathrm{~h}$ after inoculation. The bacterium was also recovered 


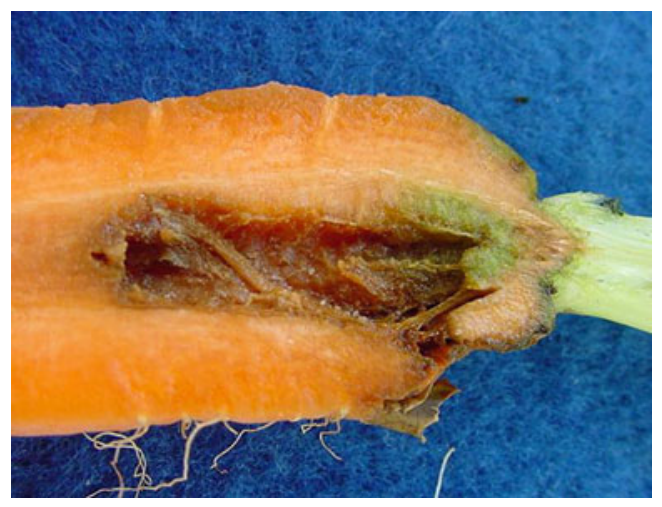

Fig. 1 Artificially infected carrot root showing disintegration of the tissues caused by Pseudomonas viridiflava

from decayed tissue (Fig. 2). Plants and carrot slices used as negative controls did not develop any symptoms.

$P$. viridiflava is a phytopathogen which can cause rot symptoms in a wide range of plant species, such as alfalfa (Medicago sativa), common bean (Phaseolus vulgaris), birdsfoot (Lotus corniculatus), cabbage (Brassica oleracea var. capitata), cauliflower (B. oleracea var. botrytis), kiwifruit (Actinidia chinensis), fennel (Anethum graveolens), grape (Vitis vinifera), lettuce (Lactuca sativa), lupine (Lupinus angustifolius), parsnip (Pastinaca sativa), passion fruit (Passiflora edulis), pea (Pisum sativum), pepper (Capsicum annuum), poinsettia (Euphorbia pulcherrima), poppy (Papaver somniferum), pumpkin (Cucurbita maxima), rape (B. napus var. napus), tomato (Solanum lycopersicum), soybean (Glycine max), and zinia (Zinnia elegans) (Goumans and Chatzaki 1998).

Losses associated with this bacterium have been reported by Young et al. (1988) where in New Zealand P. viridiflava induced severe losses in the production of kiwifruit crops especially during rainfall periods. The authors also isolated this bacterium from symptomless buds and leaves of kiwifruit. In Greece, Goumans and Chatzaki (1998) stated that P. viridiflava can cause extensive tissue necrosis on melon and tomato crops, reducing foliage by up to $50 \%$. In addition, the

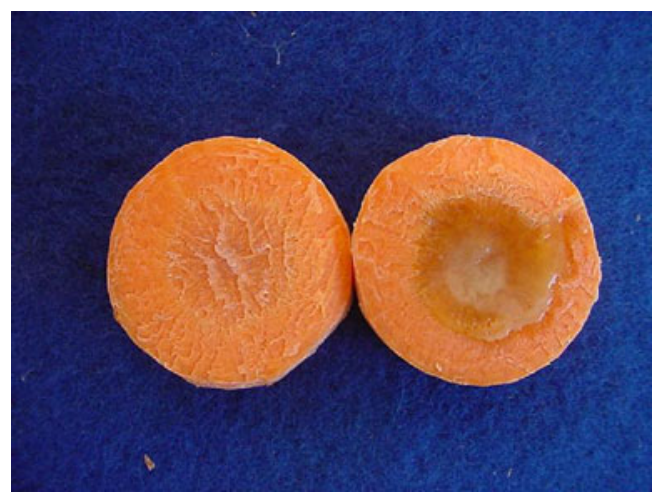

Fig. 2 Inoculation of carrot slices with Pseudomonas viridiflava. Right - rot of the tissues. Left-control bacterium caused the total destruction of 10,000 chrysanthemum plants in a Greek nursery. In the State of Georgia-USA, $P$. viridiflava was so severe that it caused the total loss in production of sweet onion (Gitaitis et al. 1991).

Apart from all of these described losses, pointed out by all of these reports, P. viridiflava is an opportunistic pathogen which can survive epiphytically either on its hosts or weeds which may act as an important source of inoculum. Disease symptoms are most likely to occur when environmental conditions such as frequent rain fall and high relative humidity favour disease development.

According to Hunter and Cigna (1981), a severe attack of a bacterial disease in fields of parsnip located in eastern New York was observed in the 1978-1979 growing season. The disease was so severe that mechanical harvesting was impossible because it destroyed the tops of the plants. Pseudomonas marginalis and $P$. viridiflava were isolated from foliar symptoms but only $P$. marginalis was recovered from diseased roots. However, P. viridiflava was isolated from symptomless roots of plants inoculated at the crown. These authors also reported that $P$. marginalis caused an extensive soft rot in carrot slices but, unfortunately, there was no data for $P$. viridiflava.

Under post-harvest conditions, Godfrey and Marshall (2002) reported P. viridiflava causing soft rot in carrots during refrigerated export from New Zealand, resulting in severe economic losses. In Brazil, Macagnan et al. (2007) described symptoms of rot caused by $P$. viridiflava in potato tubers during post-harvest storage and obtained symptoms in artificial inoculations carried out on yam (Calocasia esculenta), sweet potato (Ipomoea batatas), pumpkin (Cucurbita maxima) and chayote (Sechium edule), but not in carrot.

This is the first report of $P$. viridiflava associated with carrot seed and may explain how post-harvest damage (Godfrey and Marshall 2002) may originate from contaminated seed.

Cultures were deposited on the Phytobacteria Culture Collection of Instituto Biologico (IBSBF) under accession numbers 2320 and 2321.

\section{References}

Gitaitis RD, Baird RE, Beaver RW, Sumner DR, Smittle DA (1991) Bacterial blight of sweet onion caused by Pseudomonas viridiflava in Vidalia, Georgia. Plant Dis 75:1180-1182. doi:10.1094/ PD-75-1180

Godfrey SAC, Marshall JW (2002) Identification of cold-tolerant Pseudomonas viridiflava and P. marginalis causing severe carrot postharvest bacterial soft rot during refrigerated export from New Zealand. Plant Pathol 51:155-162. doi:10.1046/j.13653059.2002.00679.x 
Goumans DE, Chatzaki AK (1998) Characterization and host range evaluation of Pseudomonas viridiflava from melon, blite, tomato, chrysanthemum and eggplant. Eur J Plant Pathol 104:181-188

Hunter JE, Cigna JA (1981) Bacterial blight incited in parsnip by Pseudomonas marginalis and Pseudomonas viridiflava. Phytopathology 71:1238-1241. doi:10.1094/Phyto-71-1238

King EO, Ward MK, Raney DE (1954) Two simple media for the demonstration of pyocyanin and fluorescin. J Lab Clin Med 44:301-307
Lelliott RA, Billing E, Hayward AC (1966) A determinative scheme for the fluorescent plant pathogenic Pseudomonads. J Appl Bacteriol 29:470-489

Macagnan D, Romeiro RS, Macedo DM, Schurt DA (2007) Podridão em pós-colheita de batata (Solanum tuberosum) incitada por Pseudomonas viridiflava. Summa Phytopathol 33:307-308

Young JM, Cheesmur GJ, Welham FV, Henshall WR (1988) Bacterial blight of kiwifruit. Ann Appl Biol 112:91-105. doi:10.1111/ j.1744-7348.1988.tb02044.x 